\title{
Historical Analysis on Tropical Fruit Production at Coastal Sandy Farming Land in Rural Yogyakarta, Indonesia
}

\section{Subejo and Gagar Mewasdinta}

Department of Sosioeconomic Agriculture, Faculty of Agriculture, Universitas Gadjah Mada, Jl. Flora 1 Bulaksumur, Sleman, Yogyakarta, 55281, Indonesia

\section{Abstract}

As one of the autonomic district in Yogyakarta Special Region, Kulon Progo district has a huge of coastal sandy farming lands. In general, coastal sandy farming land in Kulon Progo has been widely acknowledged as common resources that the resource acess formally is owned and managed by Pakualam Ground. Various efforts in coastal sandy farming land are undertaken for improving income of coastal communities. Thanks to initiative actions of particular farmer leaders, marginal land in coastal area can be converted more productive land for agricultural production. Currently, several

Corresponding Author: Gagar Mewasdinta mewasdintagagar@mail .ugm.ac.id

Received: 10 November 2018 Accepted: 6 January 2019 Published: 10 March 2019

Publishing services provided by Knowledge E

(c) Subejo and Gagar Mewasdinta. This article is distributed under the terms of the Creative Commons

Attribution License, which permits unrestricted use and redistribution provided that the original author and source are credited.

Selection and Peer-review under the responsibility of the UASC Life Sciences 2016 Conference Committee.

\section{G OPEN ACCESS} tropical fruits such as watermelon [Citrullus lanatus (Thunb.) Matsum. \& Nakai] and papaya (Carica papaya L.) can be produced in coastal sandy land as a newly developed area. The research was conducted in Panjatan District Kulon Progo Regency in order to determine historical aspects of access and utilization of coastal sandy farming land. The method used in this research was descriptive analytic. The research results showed that historically access and utilization of coastal sandy farming land included the support of consolidation scheme of land plot arrangement incoastal sandy farming area. Community members which have been initiated by group leaders have arranged the division and allocation of coastal land for each farmer. The coastal farming land can be utilized by farmers for cultivation and farm roads building for supporting the crops production. The process has been done during 1996 to 1999. After getting coastal farming plot, farmers could manage farming land and improve the agricultural production dramatically.

Keywords: Coastal, Land consolidation, Sandy farming, Tropical fruit, Yogyakarta

\section{Introduction}

Kulon Progo district as one of the autonomic district in Yogyakarta Special Region has plenty of coastal sandy farming lands, especially in Panjatan sub-district. In general, coastal sandy farming lands in Kulon Progo locally known as common resources which belong to Pakualam Ground (abandoned land which belongs to Yogyakarta royal family), and rural farming households directly manage the access to land resources. Various 
efforts in coastal sandy farming land are undertaken to increase income of coastal communities. Thanks to pionering initiative actions and innovations of the several farmer leaders, marginal land in coastal area can be managed into productive farming land for various agricultural productions.

\section{Literature Review}

Indonesian Ministry of Agriculture released a report in 2011, which states there were $53.68 \%$ of Indonesian farmers who have farming land less than 0.5 ha per farming household [1]. Therefore, innovation on farming activities is consedarbly needed to respond a small size of land strucuture and the ownership problem in agricultural production.

Yogyakarta region is one of the most famous tourism destinations in Indonesia. However, great attention and concern has been given on common problem on the issue of agricultural land conversion and minimum of farmers' land ownership. As a tourism attraction, various food availabilty, which produced locally, is very important aspect. Unfortunately, area of agricultural productive land is decreasing simultaneously. One of the main causes of agricultural land reduction is due to land conversion into residential and industrial area construction. Farming land conversion has reached approximately 150 ha to 200 ha per yr, an amount which has to be considered seriously. The huge farming land conversion would cause a worse problem on food production capability [2].

Developing coastal sandy area as productive farming land has been regarded as appropriate solution of land conversion and small size of land ownership through a long process and mechanism. Some talented farmers have started to plant in the coastal sandy farming land since the 1980s. Those leading talented farmers in the concept of diffusion of innovation can be called as opinion leaders or innovators [3]. Opinion leaders have been playing important role in costal farming practices; they help uncertainty about new coastal farming innovations for his or her followers. The leading farmers have been introducing the conversion of marginal sandy farming land into more productive farming land, which used for agricultural cultivation and production.

Furthermore, pioneering works of innovative farmers have attracted the other farmers to join in the process. The process also gave an opportunity to farmers who have little access to farming land. Then, farmers could join to produce various crops in coastal sandy farming land. A team of researchers from Universitas Gadjah Mada (UGM) calls the process is as 'open access.' Historically, open access to coastal farming land has 
been practiced by local farmers since 1985. Farmers have started to grow chili (Capsicum annuum L.) and the other horticulture crops such as string bean (Phaseolus vulgaris L.) and other vegetables [4].

Usually, in many cases, common resources are contested by people without considering the sustainability issue of the resources which lead a phenomenon the 'tragedy of common' [5]. In the coastal sandy farming area of the southern part of Yogyakarta, to some extent tragedy of common does not occur. The tragedy of common is a condition when people only using the resources without pay any attention and invest in the sustainability of the resources [6]. Rural community behavior in managing coastal farming land can be regarded as type of Common Pool Resource Management (CRPM) based which gives more benefits for involved local people. It is also noted that internal conflicts among farmers have been quite rare in managing of coastal sandy farming lands.

Moreover, the ability of sandy coastal farmers is not only on the development of chili production, but they also could establish several tropical fruits based production especially watermelon [Citrullus lanatus (Thunb.) Matsum. \& Nakai] and papaya (Carica papaya L.). Tropical fruit became another option of earning more income for farming households. Huge stable demand for tropical fruit products has become a new opportunity for local farmers, so they could fully utilize coastal sandy farming land as productive assets for producing several agricultural products.

The purpose of this study is the identification of the historical aspects of access and utilization of coastal sandy farming land. By knowing the success story of the coastal sandy farming management by innovative farmers, it could be recommended the better strategies for spreading out the prospective innovation and improvement the chance of replication the model to the other coastal sandy farming areas.

\section{Method}

Historical analysis is used for analyzing success story of farmers on producing tropical fruit at coastal sandy farming land in rural Yogyakarta. Important aspect of history is recording and recalling the dynamic events of the past. History is also viewed as the heritage upon which the future will be better constructed. History is about preservation, recording, systematic analysis, correlation, and the interpretation of events of the past [7].

Descriptive analysis method is applied in the research. The research has been done through surveying a coastal farming group, in-depth interview to some key informants 
and direct observation on field condition of farming practices in coastal area. This method is implemented by qualitative approach.

Triangulation data and method have been conducted as data verification checked. Researchers collect and note the specifics data which closely related to the research topic. Triangulation is a technical method to test the validity and reliability of data by comparing interviews data with research result objects [8]

\section{Characteristics of Farmers in Coastal Sandy Farming Land}

In the region of Yogyakarta Province, there are three types of areas which are categorized by highland, hilly and lowland terrains. Lowland areas have a sandy land, which is $22 \mathrm{~km}$ long, $1.8 \mathrm{~km}$ wide and covers 3000 ha of sandy land area. Farmers started to cultivate sandy farming land before 1970, but they could only cultivate secondary crops on rain feed. Only a few farmers who possessed and managed irrigated paddy field could cultivate paddies. Chili farming is a type of new farming commodity in sandy land that has been introduced in the 1980s. After the initial introduction of chili farming in 1980, particular innovative farmers created a farmer group in 1985. The activities of farmer groups included land plot arrangement, land clearing, building temporary roads and uniting farmers for problem-solving. The extreme climate condition in the coastal area which includes high temperature and strong wind that affected the emergence of plant disease forced farmers to organize a planting pattern system. They also had the initiative to make a group and develop their bargaining position on harvested crop price for marketing their chili production.

Since 1985, farmers who are surrounded by coastal areas in Yogyakarta Province have been cultivating chili crops. This effort was initiated by innovative farmers in two villages in Bugel and Garongan, Panjatan Sub-district. Under the condition of marginal land, extreme climates and the greater need to access information related farming practices have forced farmers to arrange a farmer group. Collective marketing was a new invention of farmer group, it has been practiced dan developed for the past $10 \mathrm{yr}$ and has provided a better price and profit for the group members, and finally create better economic conditions for poor local farmers [9].

\section{Results and Discussion}




\subsection{Historical aspects of coastal sandy farming land}

The research results showed that historically access and utilization of coastal sandy farming land were supported by several events or steps. Table 1 shows that farmer leaders have been the initiators of several progressive innovations on agricultural production at coastal sandy farming land in rural Yogyakarta.

In the 1970s, farmers in coastal area highly depended on conventional farming land (paddy fields). Coastal land was not used as farming land for growing crops. The coastal area was covered by acacia trees (forestry area). However, several innovative farmers have started to utilize coastal land only for growing crops or plants as an additional income generation or to fulfill their daily needs. Based on information from farmer leaders, local crop variety of watermelon [Citrullus lanatus (Thunb.) Matsum. \& Nakai] and Chili (Capsicum annuum L.) production have been introduced since the 1970's. Nevertheless, it was not categorized as main agricultural production sector for ramers and farmer did not use any technology to grow agricultural crops.

Started from the condition the lack of technology on growing crops or plants in coastal sandy land, farmers in the coastal area have opened their access to the coastal sandy farming land in 1985 . They opened the access by following and implementing the success experience of farmers leaders to grow agricultural crops especially Chili in the 1980 's. Their spirit to cultivate more agricultural products in the coastal sandy area was determined by daily needs that had to be covered. They considered that income from agricultural production in conventional farming land (paddy fields) was not enough to meet their daily needs. Since 1985, farmers in the coastal area tried to manage the coastal sandy land based on their ability to open the forestry area (there were acacia trees surrounding the coastal land, and they need to cut the forest first). After that, they opened the land and chose to grow Chili based on the success story of farmer leaders and the easiness to take Chili production from the field (there was no road, and the land pattern was not well-managed, Chili production was available enough to be carried by motorcycle only).

New technology on a watering system of the farming field appeared from 1992 to 1995. This technology locally was called as panthek well irrigation system. It was similar with good irrigation in the conventional but using pipeline to dig the water from the ground. Farmers were helped by using the innovation; they just had to pump up the water with diesel machine.

In 1996, innovative farmer leaders initiated to make land consolidation through farming institution forum. The idea to manage the land was accepted by farmer groups 
TABLE 1: Historical aspects of each step and the initiators in sandy farming areas (2014 to 2016 survey).

\begin{tabular}{|c|c|c|c|}
\hline Year & Condition & Initiators & Historical Description \\
\hline 1970’s & $\begin{array}{l}\text { Lack of } \\
\text { technology }\end{array}$ & Farmer leaders & $\begin{array}{l}\text { Cropping local variety of watermelon and Chili } \\
\text { traditionally. They let the watermelon and Chili } \\
\text { growing naturally without treatment of any } \\
\text { fertilizer input and technological use. }\end{array}$ \\
\hline 1985 & $\begin{array}{l}\text { Spirit to cultivate } \\
\text { more agricultural } \\
\text { products to } \\
\text { increase their } \\
\text { income }\end{array}$ & Farmer leaders & $\begin{array}{l}\text { Open access to the coastal sandy land for } \\
\text { agricultural production area especially Chili } \\
\text { production (open access in the forestry area } \\
\text { that was built). Chili was chosen because it } \\
\text { was easier to be harvested than other crops } \\
\text { (based on farmer's leader experience). There } \\
\text { was no farming road - only several lands that } \\
\text { was cropped, based on the farmer's ability to } \\
\text { prepare the land. }\end{array}$ \\
\hline 1992-1995 & $\begin{array}{l}\text { Technology on } \\
\text { watering system } \\
\text { appeared, but still, } \\
\text { lack on farming } \\
\text { road }\end{array}$ & Farmer leaders & $\begin{array}{l}\text { Innovation about irrigation system through } \\
\text { pipeline well (sumur pantek) has been } \\
\text { developed. Watermelon was hard to be } \\
\text { harvested because of the lack in farming road } \\
\text { building to carry out the production from } \\
\text { harvesting area. }\end{array}$ \\
\hline 1996 & $\begin{array}{l}\text { Innovation in land } \\
\text { management }\end{array}$ & Farmer leaders & $\begin{array}{l}\text { Land consolidation was done by farmers in } \\
\text { order to manage the plot of coastal sandy } \\
\text { land. }\end{array}$ \\
\hline 1996-1999 & $\begin{array}{l}\text { Innovation to build } \\
\text { a farming road }\end{array}$ & Farmer leaders & $\begin{array}{l}\text { Farming roads were built. Farmers started to } \\
\text { produce tropical fruit especially watermelon } \\
\text { productively beside Chili production. It could } \\
\text { be done because the lack of harvesting fruit } \\
\text { production problem was solved by farming } \\
\text { roads building (before farming roads was built } \\
\text { it was hard to carry out the products from their } \\
\text { harvesting area). }\end{array}$ \\
\hline 2001 & $\begin{array}{l}\text { Introducing } \\
\text { horticultural crops } \\
\text { varieties which } \\
\text { were suitable to } \\
\text { be cropped in } \\
\text { coastal }\end{array}$ & $\begin{array}{l}\text { Researchers from } \\
\text { Universitas } \\
\text { Gadjah Mada } \\
\text { (UGM) }\end{array}$ & $\begin{array}{l}\text { Horticultural crops production was introduced. } \\
\text { Farmers could crop other varieties of } \\
\text { horticulture such as eggplant and mustard } \\
\text { greens. }\end{array}$ \\
\hline 2002 & $\begin{array}{l}\text { Reviewing land } \\
\text { management } \\
\text { system and } \\
\text { establishing } \\
\text { cropping } \\
\text { schedule }\end{array}$ & Farmer leaders & $\begin{array}{l}\text { Utilization of coastal sandy land reviewed } \\
\text { (including the plot and user). Cropping } \\
\text { schedule was developed, including } \\
\text { September to January for watermelon and } \\
\text { vegetables and March to July for Chili crop } \\
\text { production. Reviewing of land owner and land } \\
\text { user for fixing the farmers' institution } \\
\text { database. }\end{array}$ \\
\hline 2013 & $\begin{array}{l}\text { Introducing new } \\
\text { tropical fruit } \\
\text { variety }\end{array}$ & $\begin{array}{l}\text { Researchers from } \\
\text { UGM, and } \\
\text { impacted by } \\
\text { farmer/ fruit seller } \\
\text { from another area }\end{array}$ & California papaya production was introduced. \\
\hline 2016 & $\begin{array}{l}\text { Introducing new } \\
\text { chance to build } \\
\text { agro-tourism park } \\
\text { in coastal area }\end{array}$ & $\begin{array}{l}\text { Local Government } \\
\text { Program }\end{array}$ & Longan fruit production was introduced. \\
\hline
\end{tabular}


has made the farming plot of each farmer to be well managed. Land consolidation is the main instrument for the rural development, which has several functions with dynamic structure; to conserve the environment; to solve the marginal land problem and conflict on land ownership; to keep the tradition and the cultural value, and to get the optimum production from land management [10]. At the beginning of coastal farming land development, the plot was irregular. Then, after land consolidation was done, farmers agreed to replace their land boundary so that it could be used for farming roads construction. Figure 1 illustrates how farmer group chaired by group leaders did land consolidation mechanism. The process of establishing the farming roads building was conducted from 1996 until 1999. Farmers could get better access to their farming land and land size has been well structured.
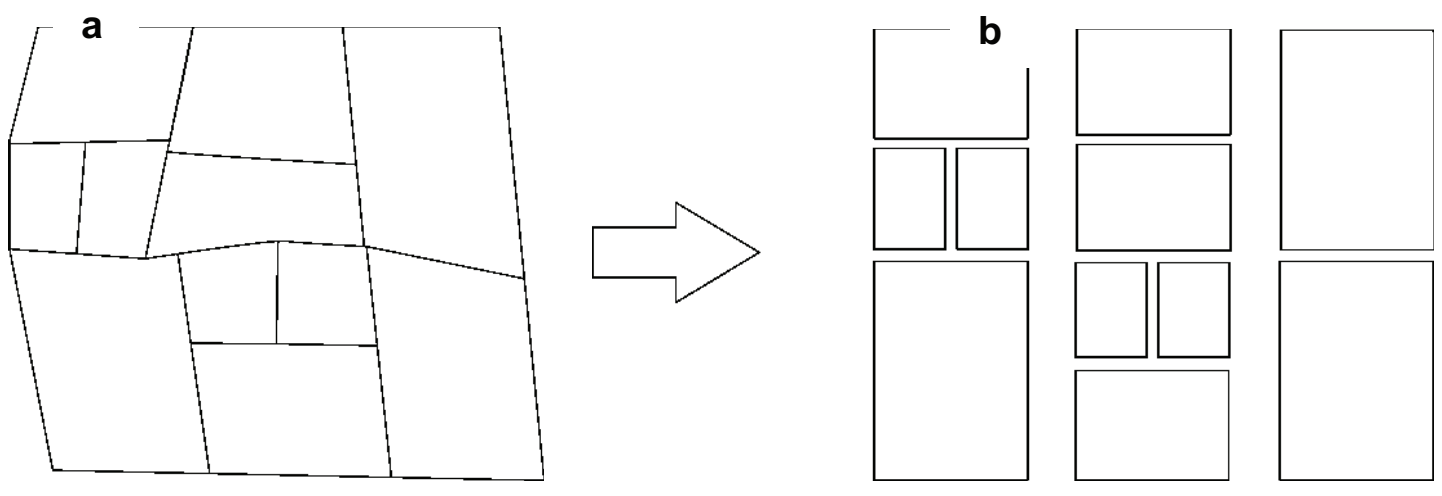

Figure 1: Land consolidation mechanism; a Before consolidation, b After land consolidation and farming roads program.

Tropical fruit especially watermelon getting more popular among coastal farmers, this crop gradually become the main crop in yearly planting cycle practiced by farmers since the success of land consolidation and farming roads development program. Farmers could have access to distribute fertilizer input to the land and be able to harvest the watermelon product directly to their land with the truck vehicle through farming roads.

A team of researchers from UGM which examined the success of coastal sandy farming land have supported by introducing another option for agricultural cropping system in coastal farming land. The researchers introduced new horticultural crop production such as eggplant (Solanum melongena L.) and mustard greens [Brassica juncea (L.) Czern].

In 2002, farmers were reviewing coastal land use data. It was needed because all of the governmental system required it as a basic data for considering new policy, especially for giving them subsidize fertilizer. Besides, it would be used to analyzing farmers, which had an affiliation with their farming institution. 
Farming activity is better than before when farmers started to do some efforts in developing their agricultural production. Annually, farmers in rural Yogyakarta have a cropping schedule which needs to be applied (especially for Chili production, because they market it collectively through auction market system, crop at the same time is needed to get the same harvest time also). The schedule contains watermelon and vegetable varieties on September to January, and then Chili production (at the same time) every March to July.

In 2013 , farmers were introduced with a new variety of tropical fruit namely California papaya [Carica papaya L. var IPB-9 (Calina / California)]. It brought by a researcher from Universitas Gadjah Mada (UGM) and farmer/fruit traders from another area. The demand for Californian papaya is still high; so many fruit traders requested the newly developed product to farmers. After the introduction of new papaya variety, currently, about $30 \%$ of farmers are planting California papaya.

In 2016, the local government of Kulon Progo has started to initiate for promoting the coastal sandy farming area as an agro-tourism area. It has been implemented by starting to grow longan plant (Dimocarpus longan Lour.) in 2 ha of farming land. The final target it will be expanded into 17 ha of longan plant in the near future. It is in line with the program from the central government of Indonesia for constructing a new international airport in the south part of the coastal area of Kulon Progo. Agro-tourism would be expected promising breakthrough and a new solution for developing the agricultural sector to be combined with the tourism sector in Kulon Progo area.

\subsection{Key event on tropical fruit production at coastal sandy farming land}

Based on historical analysis of coastal sandy farming area in rural Yogyakarta, there is an event, which becomes a turning point of the success story of a farmer on tropical fruit production. That is land consolidation and farming roads construction program from 1996 to 1999. The existence of the initiation makes farmers have more chance to enhance their tropical fruit production than before. All of the advantages are encapsulated on table 2 below.

In the future, a government program of Kulon Progo district for initiating coastal sandy farming land as a new agro-tourism destination will be new hope for agricultural production in coastal sandy farming land and will give positive growth on crops production especially on tropical fruit (watermelon, papaya, and longan). However, it must be strongly supported by central and local government, private sector, research institutions, 
TABLE 2: Analysis of the impacts resulted by land consolidation and road construction from 1996 to 1999 (2016 survey).

\begin{tabular}{l|l}
$\begin{array}{l}\text { Before Land Consolidation and Farming Road } \\
\text { was Built }\end{array}$ & $\begin{array}{l}\text { After Land Consolidation and Farming Road was } \\
\text { Built }\end{array}$ \\
$\begin{array}{l}\text { Hard to carry out fertilizer input to the farming } \\
\text { field }\end{array}$ & $\begin{array}{l}\text { Easy to carry out fertilizer input to the farming } \\
\text { field }\end{array}$ \\
$\begin{array}{l}\text { Hard to carry out harvesting product especially } \\
\text { tropical fruit production (watermelon) from the } \\
\text { field }\end{array}$ & $\begin{array}{l}\text { Easy to carry out harvesting of agricultural } \\
\text { products especially tropical fruit products } \\
\text { (watermelon)from the field }\end{array}$ \\
\hline $\begin{array}{l}\text { Land plotting was unmanaged and unorganized } \\
\text { Land plotting is well managed and organized }\end{array}$ \\
\hline Only suitable for growing agricultural crops & $\begin{array}{l}\text { Suitable to be developed as agro-tourism area } \\
\text { based on horticulture and tropical fruit } \\
\text { production system }\end{array}$ \\
\hline
\end{tabular}

and community members. More effective and higher efficiency of cultivation and management of prospective crops production system and handling which include processing and marketing system need to be accompanied and supervised by field experts and agricultural extension staffs. Better agricultural crop management system could promote farmers behavioral changes and lead higher farmers capability in maintaining agricultural production sustainability. Farmers also will have higher awareness and preparing mitigation and adaptation strategies on the environmental and global climate changes effect which possibly disturb agricultural production capacity in coastal sandy farming areas.

\section{Conclusion}

Farmers access on common resource namely coastal sandy farming land in Kulon Progo district has been started in 1985. Several agricultural products were started including horticulture crops which followed by the introduction of tropical fruit have been practiced by farmers in the coastal area. Coastal farming households get the economic impact from conducting farming production in coastal farming land.

Moreover, utilization and management of the coastal sandy farming land have been very critical point, which covered the arrangement of farming land consolidation scheme in coastal sandy farming area. It was practically conducted by dividing arranging of the farming plot for each farmer proposed for agricultural crop cultivation and farm road construction for supporting the agricultural crops production. The process has been initiated from 1996 to 1999, and from that time, farmers could significantly improve agricultural production and increase their income level through optimizing the utilization of coastal sandy farming lands. 


\section{Acknowledgments}

The authors would like to thank Mr. Karman from Panjatan sub-district, Kulon Progo district as farmer leader for supporting research team and organizing the household respondents during the field survey. This study has been funded by the Research Grant from Faculty of Agriculture, Universitas Gadjah Mada, Yogyakarta, Indonesia for the fiscal year 2016 (Research grant number is 05/2015/PN/UGM).

\section{References}

[1] Indonesian Ministry of Agriculture. Rancangan rencana strategis Kementerian Pertanian tahun 2010-2014. [Strategic plan of the ministry of agriculture in 20102014]. Ministry of Agriculture, Jakarta; 2009. p.83-87. [in Bahasa Indonesia]. http://www.pertanian.go.id/pug/admin/pengumuman/rancangan\%20renstra\% 20deptan\%202010-2014\%20lengkap.pdf

[2] Center of Assessment of Agricultural Technology. Laporan tahunan Balai Pengkajian Teknologi Pertanian (BPTP) Yogyakarta tahun 2012. [Annual report of BPTP Yogyakarta year 2012]. BPTP, Yogyakarta; 2012. p.60. [in Bahasa Indonesia]. http://yogya.litbang.pertanian.go.id/ind/phocadownload/Laporan\%20Tahunan/ Laporan\%20Tahunan\%202013.pdf

[3] Rogers EM. Diffusion of innovation. 5th ed. The Free Press, New York, 2003. p.316-322. https://books.google.co.id/books/about/ Diffusion_of_Innovations_5th_Edition.html?id=9U1K5LjUOwEC\&redir_esc=y

[4] Mewasdinta G, Jannah EN, Haryanti FN. Access and utilization of coastal sandy farming land for agricultural production in rural Yogyakarta. In: Proceeding Indonesian Student Scientific Conference (ISSC) Wageningen 2014. p.48-50.

[5] Nurjanah E, Subejo, Mewasdinta G. Land consolidation in coastal sandy farming land Kulon Progo regency. In: Seminar Proceeding of Dies Natalis of $68^{\text {th }}$ Faculty of Agriculture, Universitas Gadjah Mada 2014. p.736-739. http://www.issn.lipi.go.id/ issn.cgi?daftar\&1418363539\&1351\&\&2014

[6] Hardin G. The tragedy of the commons. Science, New Series 1968;162(3859):12431248. https://www.sciencemag.org/site/feature/misc/webfeat/sotp/pdfs/162-38591243.pdf

[7] Godfrey DG. Methods of historical analysis in electronic media. Lawrence Erbaum Associates, New Jersey; 2006. p.3-24 https://books.google.co.id/books/about/ Methods_of_Historical_Analysis_in_Electr.html?id=BqV9jQMwsHUC\&redir_esc=y 
[8] Moelong LJ. Metode penelitian kualitatif. [Qualitative research methodology]. Remadja Karya, Bandung; 2010. p.330-331. [in Bahasa Indonesia]. https://books.google.co.id/books?id=YXsknQEACAAJ\&dq= Moleong.+Qualitative+Research+Methodology\&hl=id\&sa=X\&ved= OahUKEwiUrqjmjpvZAhUCOJQKHVVWBQEQ6AEIPDAD

[9] Raya AB. Farmer group performance of collective Chili marketing on sandy land area of Yogyakarta Province Indonesia. Asian Social Science 2014; 10(10):6-11. http://www. ccsenet.org/journal/index.php/ass/article/view/36484

[10] Gür M, Cagdas V, Demirel Z. Land consolidation as a tool of rural sustainable development. Second FIG Regional Conference, Morocco December 2-5 December 2003. p.1-12. https://www.fig.net/resources/proceedings/fig_proceedings/morocco/ proceedings/TS4/TS4_3_gur_et_al.pdf 